\title{
Capital town
}

Dorkas waits in front of her house in Lawonda for the small buss that collects travellers to Waikabubak. It is just after sunrise. She wants to go to town to visit the hospital. She has been feeling very tired during the last several months with fevers every two weeks, and the nurse in the village clinic had not given her a diagnosis and the right medicine. An older woman joins Dorkas in the buss; she is going to see her daughter in town. Two young girls get on board. They have attended their uncle's funeral in the village, and now they have to hurry back because they only had permission to be absent from secondary school for three days. At the next corner, a middle-aged man carrying a small pig steps in. He desperately needs money to pay school fees for his son. In town he will get a better price for the pig than here in the village. Descending to Anakalang the road is rather bumpy. The surface had been rehabilitated last year, but there are already large holes in the middle of the road. People blame the contractor, who surely used the cheapest materials and put the rest of the money in his own pocket. The driver puts a new tape in the recorder and cheerful Christian pop music provides enjoyment for the passengers.

Waikabubak is the capital town of West Sumba. In 2002 it had 23,000 inhabitants, which is only about 6 per cent of the total population of this District. The capital is much more important than a meagre ' 6 per cent' suggests. Many people stay there temporarily: as a guest in the house of their children, as a pupil in a boarding school, as a casual labourer as long there is work to do. Members of West Sumba's wealthier class often have a house in Waikabubak and a house in their home village. They live in town during the week when they go to work, and in the weekend they spend their time in the village. Some of them have a house in the provincial capital Kupang as well, or even on Java. In Waikabubak they can use their cell phones and send text messages to places outside Sumba, which is the easiest, fastest and cheapest way of communicating with the world outside the island. Groups of relatives, working youth and school children live in the houses of one of the wealthy landlords. Part of the group switches residence very often, including the landlord himself. A wider circle of relatives considers these houses kita 
punya rumah sendiri, ${ }^{1}$ our own home, and they feel welcomed to stay there whenever it suits them.

The Dutch East Indies government chose Waikabubak as the administrative capital of the southwest part of the island after the pacification of Sumba by the Dutch army in 1913 (Van den End 1987:686). One Dutch gezaghebber was stationed in town. In the same period the Dutch Protestant Christian missions also chose Waikabubak as a centre of their activities. Missions had several criteria that preferably had to apply to new posts. They had to be located in densely populated areas, with relatively easy access and other suitable qualifications of a regional centre, not far from a sea harbour, with good supply of water and a relatively cool climate. ${ }^{2}$ Waikabubak is originally the name of a spring (wai means water) that provided water for a large valley in which many garden houses and cultivated lands are located. One of the first activities of the colonial government was to construct roads connecting the centres of administration, mission and trade. Waikabubak was connected, via Anakalang, to Waingapu, and to the north with the harbour Waikelo. In 1925, the Christian missions opened the first hospital in Waikabubak, headed by the Dutch doctor J. Berg. In that year there were 250 Christians in southwest Sumba (Wielenga 1949:220).

Since that time the capital has also been a centre for health care in West Sumba, and it still is in 2005. The Christian hospital in the centre of town looks worn out. The new Public Hospital (Rumah Sakit Umum) just outside town is the better alternative, where one can visit even specialist doctors. Yet, people who can afford it go to Bali or Java for treatment when there is a really serious illness. The director of the public hospital is a very popular Sumbanese doctor from Kodi and in June 2005 he was chosen as deputy District Head (see Chapter XI). The Christian congregation of Waikabubak is not very old: it was installed in 1937, as the second congregation in West Sumba after Rara (Wielenga 1949:220). The first Sumbanese reverend at Waikabubak was H.M. Malo, the father of Manasse Malo, a professor at the Universitas Indonesia in Jakarta since the 1980s, who was very important for Sumbanese politics in 2002-2004 (see Chapter VIII). In 1947 the first (Christian) secondary school (SMP) was established in Waikabubak, and it took until 1960 before this town, and West Sumba in general, had its own SMA (junior high school). The former pupils of this high school now make up a social network connecting many people with influential positions.

Waikabubak around the year 2000 is a widely stretched town, with a ribbon-

$1 \quad$ Kita punya rumah sendiri is also an expression that refers to the network of close social relations in which resources are exchanged in generalized reciprocity. See Vel 1994:159.

2 'Motieven voor keuze van een plaats als zendingspost', Letter from J.F. Colenbrander 27-08-1911 in Van den End (1987:158-9). 
like building pattern along the main roads that extend in all cardinal directions. Coming in from the direction of Anakalang and Lawonda in the east, a modest arch welcomes the visitor to Waikabubak. It is about four kilometres from the centre. Since 1998 many new houses have been built along the main road and the style is getting fancier every year. The best have spotless whitetiled verandas and walls, and windows with black tainted glass. Traffic gets busier as one approaches the town centre. The absence of sedan cars reflects the bad quality of the roads in West Sumba; such a car could only be used in town. In 2002 the statistics office counted 1400 motorcycles in West Sumba, and many of these often come to town. It is the cheapest and fastest mode of transport.

The surroundings of Waikabubak include a large plain with some singular hills. The old kampongs built on these hills are still there. They used to be central villages of the Loli area, and now they are rural islands in the middle of modern Indonesian 'urban' life. The original inhabitants of this area, called orang Loli, lament having lost their land to traders and bureaucrats that came to town since it first gained importance as district capital. On the other hand they exploit the traditional spots as tourist attractions. Kampong Tarung is the most famous kampong, according to the Lonely Planet guide:

reached by a path next to the Hotel Tarung Wisata or off Jalan Manda Elu, Kampung Tarung is one of the most important ritual villages for the whole valley. It is the scene of an important month-long ritual sequence, the Walu Podu, each November. This is an austere period when even weeping for the dead is prohibited. Rites consist mainly of offerings to the spirits the day before it ends, when hundreds of chickens are sacrificed. People sing and dance for the entire final day. Tarung's monuments are under official protection. You might also be shown a human skin drum held in the village. (Turner 1998:377.)

When the author of this text in the Lonely Planet guide wrote the lines in 1998 it was only a few months before the rituals he described became part of a war in the streets of Waikabubak. Just as the old Kampong Tarung became situated in the middle of a modern town, the traditional rituals became part of a modern political conflict that is analysed in the next chapter.

The centre of the town is composed of five or six streets. One is the main shopping street. There are no fancy shops selling expensive or elegant goods, let alone a shopping mall. The typical shop is the general Chinese retail toko, with hardly any specialization, and always with small vendors in front. I have been well acquainted with one of the Chinese families who own a shop in Waikabubak's main street since 1984. Like most shop owners, their shop is just one of many activities in which they participate. They sell groceries, some shoes, and spare parts for machines and cars. They also have a considerable number of trucks that they use for transporting their own commodities and 
also for renting out. They own a ship that brings in goods from Surabaya and travels back with agricultural produce, livestock and with whatever load needs to be transported to Java. They are also contractors and can take charge of construction projects. They are the agent for one of the airlines that flies to West Sumba's airport, Tambolaka. The family resides behind the shop when they are in Waikabubak. They can watch TV with a satellite receiver that catches over $170 \mathrm{TV}$ stations from all over the world. The family often goes to Surabaya where they have a second home. They occasionally make a trip to relatives in Singapore or Hong Kong. They are very well informed and intelligent discussion partners, especially when it comes to assessing the economic potential of Sumba.

From the early 1990s until 2002, the number of hotels in town grew to six. The most expensive is Hotel Manandang that charged about 20 US dollars per room in 2004, which is extremely expensive by Sumbanese standards. Its guests are tourist groups, but more often it is occupied with those who attend the numerous workshops or seminars organized by government agencies or NGOs. Since the effectuation of regional autonomy the district government has much more money to spend and construction of new hotels is one of the outcomes of this situation. In the 1990s the District government already decided to upgrade its own dwellings: they built a new centre at the outskirts of town with a prestigious parliament hall and office of the bupati. The parliament members all received a new car. With the same conspicuous style the old Christian church of Waikabubak was replaced by the end of the 1990s with a huge pseudo cathedral, showing most of all the wealth of the town-congregation's members.

There is nothing much to do in Waikabubak, generally. Once in a while there is an event at the sports stadium in the middle of town. There is no cinema or game hall. There is a horse race stadium, but races are sporadic. 